\title{
Mellom entré og sorti - dramaturgisk didaktikk i klasserommet
}

\author{
Kristin Helstad ${ }^{1 \star}$ og Per Arne Øiestad ${ }^{2}$ \\ ${ }^{1}$ Hogskolen $i$ Innlandet, Norge og ${ }^{2}$ Hartvig Nissens Skole, Norge
}

\begin{abstract}
Sammendrag
Undervisning består av komplekse handlinger der lærere leder læringsprosesser og kontinuerlig må balansere ulike hensyn opp mot hverandre. Å tenke som en dramaturg kan bidra til å bevisstgiøre og profesjonalisere det didaktiske arbeidet i klasserommet. I denne artikkelen undersøker vi hva dramaturgisk didaktikk kan innebære, og vi ser nærmere på hvordan dramaturgiske begreper og verktøy kan stimulere og utvikle lærerens iscenesettelse av undervisning. Artikkelen er et teoretisk bidrag til klasseromforskning der et læringsperspektiv på undervisning koples med et dramaturgisk perspektiv. Til grunn ligger en praksisrettet forskningstilnærming, der en lærer i drama- og teaterfag i videregående skole har samarbeidet med en skoleforsker om å utvikle nye forståelser av didaktisk arbeid.Vi illustrerer tenkningen i form av en læringssirkel, der aristotelisk dramaturgi og begrepene entré og sorti rammer inn en begynnelse og en slutt i et undervisningsforløp. Dramaturgisk didaktikk forstås som virksomme handlinger som blir satt i spill i dette mellomrommet, der læreren tilrettelegger for læring i klassefellesskapet, og der elevene over tid får bryne seg på faglig og relasjonelt arbeid. Ved å hente inspirasjon fra regissørens arbeid i teatret, viser vi at en dramaturgisk tenkemåte kan ha sterk forklaringskraft for arbeid i klasserommet.
\end{abstract}

Nøkkelord: dramaturgisk didaktikk; klasseromsforskning; laringssirkel; praksisrettet forskning; undervisningsforløp

\begin{abstract}
Between 'entrance' and 'exit' - dramaturgical didactics in the classroom

Teaching consists of complex actions where teachers lead processes of learning and continuously have to balance different considerations. Using dramaturgy as a tool helps raise awareness and professionalize teachers' work in the classroom. In this article, we examine what dramaturgical didactics might entail, and how dramaturgical concepts and tools may stimulate and develop teaching. The point of departure is a practice-oriented research approach where a teacher in drama in upper secondary school collaborated with a school researcher on understandings of teaching. The article is a theoretical contribution to classroom research where we combine a learning perspective and a dramaturgical perspective. We illustrate the theory by presenting a dramaturgical learning circle that may serve as a tool for teaching. The concepts of 'entrance' and 'exit' frame a beginning and an end in a teaching process. Dramaturgical didactics involve active actions, where the teacher facilitates for a fruitful learning community and where the students, over time, work on the subjects
\end{abstract}

^Korrespondanse: Kristin Helstad, e-post: kristin.helstad@inn.no

(C) 2021 K. Helstad \& P. A. Øiestad. This is an Open Access article distributed under the terms of the Creative Commons Attribution 4.0 International License (https://creativecommons.org/licenses/by-nc/4.0/), allowing third parties to copy and redistribute the material in any medium or format and to remix, transform, and build upon the material for any purpose, even commercially, provided the original work is properly cited and states its license.

Citation: K. Helstad $\mathcal{E} P$. A. Øiestad. «Mellom entré og sorti-dramaturgisk didaktikk $i$ klasserommet». fournal for Research in Arts and Sports Education, Special issue: Dramaturgiske perspektiver på didaktiske kontekster, Vol. 5(2), 2021, pp. 24-38. 
and the resources at play with learning as the ultimate goal. Although the dramaturgical learning circle is developed in a specific context, the underlying thinking might be used in similar contexts. By drawing inspiration from the director's work in the theater, the article illuminates that a dramaturgical way of thinking may have a strong explanatory power for teachers' work on all educational levels.

Keywords: dramaturgical didactics; learning circle; classroom research; practice-oriented research; teaching process

Received: October, 2020; Accepted: April, 2021; Published: June, 2021

\section{Innledning}

Lærerarbeidet, enten det er i en lærerutdanningskontekst eller i skolen, er komplekst og sammensatt, og vi trenger tilfang av flere teorier og begreper for å gi det forklaringskraft. Mens pedagogiske og fagdidaktiske teorier har til hensikt å gi språk til læring som finner sted $\mathrm{i}$ et klasserom, kan estetiske tilnærminger tilby alternative måter å begrepsfeste læringsarbeidet på. Kunstfagene tilbyr muligheter for å beskrive det didaktiske arbeidet med en større følsomhet for situasjonen enn tradisjonelle forståelser gjerne bidrar med (Dale, 1991). Med hensikt om å fornye didaktisk teori om undervisning og klasseledelse, har Østern (2014) utforsket hvordan dramaturgisk tenkning kan overføres til didaktisk virksomhet. Bakke \& Lindstøl (2021) har utviklet tenkningen ytterligere ved å vise hvordan dramaturgiske analyser kan bidra til forskningen. Å tenke på lærerens arbeid som regi og iscenesettelse av undervisning kan tilby en nyansert forståelse og åpne for nye måter å beskrive og forstå det komplekse klasserommet. Et dramaturgisk perspektiv har potensiale til å fornye måter vi tradisjonelt tenker om undervisning og sette ord på måter lærere iscenesetter undervisning som virksomme handlinger som bidrar til elevenes læring. ${ }^{1}$ Nyere klasseromforskning dokumenterer at det som skjer mellom lærere og elever og hvilke ressurser som er til rådighet i undervisningssituasjonen har stor påvirkningskraft for resultater som oppnås og for hvordan elevene trives og tar til seg kunnskap (Klette, 2020, s. 190). Didaktikken som iscenesettes i klasserommet i form av prosesser som initieres, følges opp og avsluttes gientatte ganger, er lærerens viktigste verktøy i undervisningen.

Hensikten med denne artikkelen er å utforske hvordan dramaturgisk tenkning kan supplere tradisjonelle forståelser og bidra med alternative tenkemåter og idétilfang til undervisning og læringsarbeid. Vi spør: Hva innebærer dramaturgisk didaktikk, og hvordan kan dramaturgiske verktøy stimulere og utvikle lærerens iscenesettelse av undervisning? Ståstedet vårt er i klasserommet og det didaktiske arbeidet lærere regisserer for.

\footnotetext{
${ }^{1}$ Begrepet dramaturgi kommer fra det greske ordet drama, som betyr handling, mens -urgi er avledet av det greske ordet ergon, som betyr å være virksom. Vi bygger her på en aristotelisk og tekstbasert teatertradisjon som utgangspunkt for vår forståelse av dramaturgi.
} 
Dramaturgibegrepet relateres gjerne til arbeid i teatret. Szatkowski (1989, s. 122) knytter dramaturgi til læren om dramaets funksjoner og transformasjonen fra idé til forestilling. I utdanningskontekster kommer dramaturgibegrepet til uttrykk i for eksempel nye læreplaner i dramafag i videregående skole, der dramaturgi omtales som sceniske og dramaturgiske innganger og virkemidler. Elevene skal reflektere over dramaturgiens muligheter og effekter, og de skal utforske hvordan dramaturgi som fagfelt kan brukes for å forstå strukturer også utenfor teatret. ${ }^{2}$ I aristotelisk dramaturgi er handlingen den viktigste bestanddelen mellom en begynnelse, som blir etterfulgt av noe, en midte, som følger etter noe annet og blir etterfulgt av noe, og en slutt som følger etter noe, men som ikke nødvendigvis blir etterfulgt av noe annet (Gladsø et al., 2015, s. 29). Overfører vi denne tenkningen til klasserommet, kan handlingsdimensjonen synliggjøre hvordan et faglig innhold kan transformeres til undervisning, der begrepene entré og sorti kan ramme inn en begynnelse og en slutt i et forløp, fra der læreren møter elevene til undervisningsforløpet avsluttes. Dramaturgiske begreper som tid, rom, kropp og tekst kan være innganger til å definere et didaktisk handlingsrom. Med inspirasjon fra dramaturgi og et kunstfaglig blikk (Østern, 2014) i kombinasjon med teorier om didaktikk og læring (Bjørndal \& Liberg, 1978; Engestrøm \& Sannino, 2010) utvikler vi nye forståelser av undervisning og didaktikk. Bidraget er teoretisk, men til grunn ligger en praksisrettet forskningstilnærming der en lærer i drama- og teaterfag i videregående skole har samarbeidet med en skoleforsker over tid for å utvikle teorier om ledelse og læring i klasserommet (Helstad \& Øiestad, 2017). Forskningen har blant annet utkrystallisert seg i form av en dramaturgisk læringssirkel som beskriver faser $\mathrm{i}$ et undervisningsforløp og som presenteres her. I det følgende går vi nærmere inn på hva didaktikk i et dramaturgisk perspektiv kan innebære. Deretter presenterer vi forskningsdesignet og den metodiske tilnærmingen som ligger til grunn før vi introduserer den dramaturgiske læringssirkelen. Vi drøfter dette verktøyets potensiale i relasjon til en dramaturgisk didaktikkforståelse før vi sammenfatter og peker på mulige implikasjoner for videre forskning.

\section{Klasserommets didaktikk og dramaturgi}

Enkelt sagt dreier didaktikk seg om hva som skal undervises og læres, hvordan det skal undervises og læres, og i hvilken hensikt noe skal undervises og læres (Gundem, 2008). Tradisjonelt forstås didaktikk som teorier om undervisning mer generelt, og som teori og praksis knyttet til undervisning og læring i det enkelte fag, omtalt som fagdidaktikk. Det er i undervisningen at den didaktiske teoriens relevans for praksis prøves, der den faglige kompetansen spiller sammen med den didaktiske kompetansen. Innenfor didaktisk relasjonstenkning, som er utviklet av norske pedagoger og som har fått stor utbredelse, forstås undervisning som en dynamisk prosess, hvor de

${ }^{2}$ I læreplanen for faget teater i perspektiv på musikk, dans og dramalinjen i videregående skole, er dramaturgi ett av tre kjerneelementer i faget (Utdanningsdirektoratet, 2021) 
didaktiske dimensjonene gjensidig påvirker hverandre (Bjørndal \& Liberg, 1978). Til grunn ligger det en forestilling om den profesjonelle lærer, som reflekterer over og planlegger undervisning $\mathrm{i}$ lys av utdanningens formål, mål med undervisningen som er forankret i læreplaner, elevenes og lærernes forutsetninger, samt undervisningens innhold, arbeidsmåter og vurderingsformer.

Utforming av delene i et undervisningsforløp kan ifølge Lindstøl (2017) betegnes som undervisningens dramaturgi. En didaktisk orientert dramaturgi tar utgangspunkt i den didaktiske relasjonstenkningen som analyseredskap i refleksjoner over undervisning, men supplerer tenkningen med et prosessuelt perspektiv der undervisning også forstås som et forløp. Dramaturgiske perspektiver kan hjelpe lærere med å identifisere og utvikle undervisningens ulike faser. Det kan dreie seg om å forstå samspillet som utvikles mellom aktørene i klasserommet, på hvilke måter fagstoff kan iscenesettes og hvilke varierte arbeidsformer og vurderingssituasjoner lærere kan tilrettelegge for. Et dramaturgisk perspektiv synliggjør hvordan et faglig innhold kan introduseres, bearbeides, levendegiøres og internaliseres som kunnskap. Lærerens språklige innramming av et undervisningsforløp er for eksempel viktig for hvordan det oppfattes. Bakke (2019, s. 7) viser at det kan være forskjell på hva et skriveoppdrag er, som idé og tekst, og hvordan det introduseres for elevene, og hva det blir, som iscenesatte hendelser $i$ et klasserom. Dramaturgiske analyser av undervisning gir tilgang til å utforske og forstå helhet og sammenhenger i undervisningsforløp.

Lærere har som sitt primære oppdrag å gi retning og motivasjon til elevenes læringsprosesser (Helstad \& Øiestad, 2017). For at elevene skal ha gode læringsvilkår, viser klasseromforskning fram betydningen av hva lærere gjør, og hvilke verktøy lærere anvender i undervisningen i fagene, som i norskfaget på ungdomstrinnet (Blikstad-Balas \& Roe, 2020). Slike verktøy kan dreie seg om hvordan lærere bygger og utvikler læringsmiljøet i klassen, hvordan de gir faglig tilbakemelding til elevene, og hvordan bruk av ulike arbeidsmåter gir støttestrukturer for elevenes læring. I klasserommet er læreren leder med ansvar for å etablere gode rammer for undervisningen, å utvikle gode læringskulturer og samspill i fellesskapet, og ikke minst, å tilrettelegge for elevenes læringsprosesser. Klette (2020, s. 90) omtaler læreres tilrettelegging av undervisning som tilegnelsessituasjoner, utprøvingssituasjoner og konsolideringssituasjoner, der det er viktig å finne en god balanse mellom de ulike delene. Vi vil argumentere for at etableringssituasjoner, der lærere etablerer kontakt med elevene og bygger relasjoner, også utgjør en sentral del av en slik balanse. Dette vil vi komme tilbake til i presentasjonen av den dramaturgiske læringssirkelen.

Når lærere planlegger undervisning, vet de at ulike scenarioer kan utspille seg, at planer må justeres, og at resultater er avhengige av en rekke faktorer både i og utenfor klasserommet som lærere kan ha mer eller mindre kontroll over. Teorier om ekspansiv læring, som blir definert som "to learn something that is not yet there» (Engestrøm \& Sannino, 2010, s. 2), kan gi forklaringskraft til det didaktiske arbeidet og hjelpe lærere til å håndtere lite forutsigbare læringssituasjoner. Ekspansive læringsprosesser innebærer å skape nye aktiviteter og ny kunnskap sammen med elevene, der læreren 
framstår som en tydelig leder og regissør (Helstad \& Øiestad, 2017). Når læreren er regissør, kan vi tenke oss klassen som et ensemble som skal produsere noe sammen, ikke ulikt teaterregissørens arbeid med sitt ensemble. En viktig forskjell ligger i formålet med arbeidet; mens regissøren har det kunstneriske ansvaret for en teaterproduksjon med en forestilling av høy kunstnerisk kvalitet som mål, er lærerens prosjekt å tilrettelegge for elevenes læringsprosesser og oppfylle læreplanens intensjoner. På tross av ulike formål kan prosessene teaterensemblene og elevfellesskapene går gjennom likne hverandre, og det er i prosessene fram mot et sluttprodukt (en premiere eller avslutning på et undervisningsforløp), at teorier om ekspansiv læring og en dramaturgisk orientert didaktikk kan tilby lærere verktøy og tenkeredskaper (Eri \& Aas, 2020). Hvordan lærere arbeider med undervisning og læring, kan også omtales som kunnskapsarbeid (Hermansen, 2018, s. 13). Kunnskapsarbeidet er en integrert del av lærerarbeidet og kan forstås både som individuelle handlinger utført av enkeltlærere og som prosesser som utspiller seg i kollegialt samspill. Didaktikken som iscenesettes gjennom undervisning på alle nivåer i utdanningssystemet, er innvevd i dette kunnskapsarbeidet.

\section{Forskningsdesign og metodisk tilnærming}

Forskningstilnærmingen som ligger til grunn for denne artikkelen, benevnes som praksisrettet forskning (Postholm \& Smith, 2017, s. 82) og teacher research (CochranSmith \& Lytle, 2009) og plasserer seg innenfor aksjonsforskning som overordnet forskningsstrategi. Aksjonsforskning er på jakt etter forbedringer som krever engasjement og medvirkning fra deltakerne. Forskningstilnærmingen er ofte brukt både i drama- og teaterforskning (Eriksen \& Leming, 2020) og i pedagogisk forskning, der lærerutdanningsmiljøer samarbeider med skoler (Hiim, 2020). I praksisrettet forskning er det lærere, ofte i samspill med kolleger eller elever, som er igangsettere av utviklingsprosesser (Allern \& Sæbø, 2010). Forskningen kommer innenfra, fra profesjonen selv, og baserer seg oftest på en kvalitativ tilnærming. Dette gjelder også her, der forskerne har hatt innside-erfaring med praksisene de har studert og der de har samlet materiale over tid. I studien har vi vært to forskere, læreren i teaterfag og en forsker som også er lærerutdanner. Begge er forfattere av denne artikkelen. Tilnærmingen er basert på systematisert kunnskap der læreren over flere år har forsket på egen praksis som lektor i faget teaterproduksjon på musikk-, dans- og dramalinjen ved en videregående skole. Som aktører i feltet har begge vært deltakere og observatører og deltatt i beskrivelser og fortolkninger av arbeidet. ${ }^{3}$ Parallelt har forskeren og læreren hatt kontinuerlige dialoger for å reflektere over erfaringer og utvikle dramaturgisk tenkning om undervisning.

\footnotetext{
${ }^{3}$ Det empiriske grunnlaget omfatter ulike undervisningsopplegg, observasjoner av elevers arbeid, feltnotater, logger og samtaler med elever og kolleger. Dette blir ikke nærmere redegjort for her, men danner et viktig bakteppe for utforming av den dramaturgiske læringssirkelen.
} 
Den dramaturgiske læringssirkelen som presenteres i neste del av artikkelen, har utkrystallisert seg som en måte å tenke på om både kortere og lengre undervisningsforløp, og bidrar med et teoretisk blikk på didaktiske kontekster. Læringssirkelen har blitt til gjennom gjentatte utprøvinger av ulike modeller og skriftliggiøringer av refleksjoner, der empiri fra klasserommet har blitt kombinert med kunstfaglige og læringsteoretiske perspektiver. Teoretiseringen av arbeidet har blitt til i samarbeid, der læreren og forskeren har framstått som likeverdige bidragsytere når det gjelder å gi mening til og fortolke aktivitetene som har foregått. Forskningsdesignet er på denne bakgrunnen basert på et innenfra-perspektiv i kombinasjon med et utenfraperspektiv, der lærerens erfaringer er teoretisert i samarbeid med forskeren (Alvesson \& Sköldberg, 2010). Kvernbekk (2005, s. 41) spør hvordan innside-forskning kan bevege seg fra det private og erfaringsbaserte til felles, intersubjektive oppfatninger og derfra til pålitelige beskrivelser av et fenomen, og konkluderer med at «til det trenger vi andre». Å ta et metaperspektiv på seg selv og egen praksis er en ferdighet som kan oppøves gjennom refleksjon og gjennom samtaler med andre, som eksterne forskere. Kvernbekk skiller mellom insiderbaserte erfaringer (om hvordan det er å være lærer), aktiviteter (yrkesutøvelsen i praksis) og performance (aktørenes handlinger). Mens aktiviteter og handlinger kan observeres av andre, er erfaringene genuint insiderbaserte, mens outsidere kan være en kilde til å språkfeste kunnskap ved å bidra til å rekonstruere aktørenes erfaringer. Å få tak i intensjonene bak handlingene gir informasjon til forskere som er på jakt etter å forstå hva som skjer på innsiden av aktivitetene. Selv om en insiderposisjon og en outsiderposisjon i prinsippet utgiør motsatser, kan det i praksis være glidende overganger. I dette tilfellet har forskeren (outsideren) lang erfaring som lærer i ungdomsskolen med drama som et av fagene hun har undervist i. Hun har «hatt på seg skoa» og kan lett kjenne seg igjen i lærerperspektivet. Ved siden av lærerarbeidet har læreren (insideren) hatt oppdrag som læreplanutvikler, kursholder og lærebokforfatter, noe som har bidratt til et større analytisk blikk på egen praksis. Lærerens undervisning og refleksjoner både i forkant og etterkant av ulike undervisningsforløp har vært gjenstand for kontinuerlig analyse og forhandlinger. Sammen har læreren og forskeren utviklet en langsiktig dialog med et utforskende blikk på praksiser de begge har vært del av, en dialog som blant annet har resultert i undervisning over slike temaer i lærerutdanning og i etterutdanning for lærere, samt i faglitteratur med boken Lareren som regissør (Helstad \& Øiestad, 2017).

I kvalitativ forskning er forskeren et sentralt verktøy når ny kunnskap skal frambringes, og forskeren er selv med på å konstruere eget undersøkelsesobjekt (Kvale \& Brinchmann, 2015). Begrensningene ved en praksisrettet forskerrolle er knyttet til metodiske og etiske utfordringer som dreier seg om at praktikere kan ha for lite distanse til feltet, noe som stiller store krav til systematisk analyse og datatransparens. En annen begrensning dreier seg om at lærerforskningsprosjekter kan bli for individuelle og svakt forankret i skoleorganisasjonen. Utviklingsarbeidet som foregår kan lett bli personavhengig og i mindre grad kollektive utviklingsprosesser som kommer flere til gode (Christoffersen, 2011). På den annen side kan det argumenteres med at 
når lærere forsker, er det en styrke at ny innsikt forankres i profesjonell praksis (Hiim, 2020). I denne studien har samarbeidet mellom læreren og forskeren bidratt til validitet i forskningen, der refleksjoner og kritiske spørsmål knyttet til undervisning og læringsarbeid i flere klasser over et lengre tidsrom har blitt systematisert. Ulike versjoner av den dramaturgisk-didaktiske tenkningen har blitt lagt fram for andre lærere og forskere som har bidratt med konstruktiv respons. Artikkelen er et bidrag til at den praksisrettede forskningen ikke forblir taus og individuell, men eksplisitt og tilgjengelig for et kollektiv av forskere og praktikere.

\section{Dramaturgisk didaktikk som læringssirkel}

For å illustrere dramaturgisk didaktikk har vi utviklet en læringssirkel som beskriver gangen i et undervisningsforløp og der vi lar lærerens arbeid i klasserommet speile seg mot regissørens arbeid i teatret. Hensikten med dette er ikke å sammenlikne profesjonene, men å belyse og inspirere klasseromsarbeidet ved hjelp av teaterfagets teori og praksis. Arbeidet med å sette opp en teaterforestilling er en skapende prosess som går gjennom faser med sine særpreg. På samme måte kan vi forstå undervisning som skapende arbeid som beveger seg gjennom faser av kortere og lengre varighet.

\section{Fra etableringsfase til konsolideringsfase}

I de første fasene i et undervisningsforløp, slik vi viser i læringssirkelen, etablerer læreren kontakt med elevene og inngår et langsiktig relasjonsarbeid som blir omtalt som hjørnesteinen i god klasseledelse (Helstad \& Øiestad, 2017, s. 75). Før det faglige arbeidet kommer skikkelig i gang, forhandler læreren med elevene om forståelser av oppdraget, om hva de skal i gang med og hva de skal ende opp med i perioden. I tråd med læreplanens forventninger, og med læreren som en tydelig leder, involveres elevene i planleggingsprosesser av det videre forløpet. I utøvelse av ledelse er dialogen og samhandlingen aktørene i mellom sentral for å skape mening og tilslutning til oppdraget (Møller, 2019). I denne etableringsfasen kartlegger læreren dynamikken i elevfellesskapet for å tilrettelegge for et best mulig læringsmiljø og for å kunne forankre det faglige arbeidet relasjonelt og sosialt i elevfellesskapet. Undervisning i og på tvers av fag har en tendens til å likne hverandre i en oppstart- og en avslutningsfase, mens hoveddelene i et forløp kan være svært forskjellige (Bakke, 2019, s. 7). De neste fasene i læringssirkelen rommer det prosessorienterte læringsarbeidet, der muntlige og skriftlige tekster i ulike formater og sjangre (jf. et utvidet tekstbegrep) er i omløp. I likhet med regissøren har læreren ansvar for å gjøre fagenes tekster levende og relevante for elevene. Der skuespillere fortolker et manus som skal ta scenisk form, må elevene kunne utforske tekster ved å prøve ut begreper og betydningslag $i$ et fortolkende kunnskapsarbeid (Hermansen, 2018). Når arbeidet nærmer seg konsolideringsfasen, kan ny kunnskap bli integrert og innvevd i elevenes forståelser. Klasseromforskning viser at konsolideringsfasen ofte er svakt forankret i undervisningen (Klette, 2020). I beskrivelsen av denne fasen i læringssirkelen har vi 
lagt vekt på betydningen av å sette et punktum. Undervisningens dramaturgi trenger etableringsfasens entré og konsolideringsfasens sorti for å ramme inn en begynnelse og en slutt $i$ et undervisningsforløp. Læringssirkelen kan fungere som et verktøy for å planlegge et undervisningsforløp, for å forstå og tolke et fagstoff, for å tilrettelegge for varierte arbeidsmåter underveis, og for å analysere og evaluere et avsluttet forløp. Tenkningen kan anvendes ved mindre formater, som undervisningsforløp over en dobbeltime eller et opplegg over noen timer, og ved større formater, som forløp som strekker seg over et semester eller et år. I dette arbeidet blir prosessen vel så viktig som produktet, og faseinndelingen gir grunnlag for bedre å kunne identifisere hvor læringsarbeidet befinner seg i prosessen. Innenfor den sirkulære framstillingen har læreren stort handlingsrom til selv å utforme dramaturgien.

Vi har inndelt læringsarbeidet i sju faser: 1) møte med ensemblet, 2) forhandlinger om oppdraget, 3) rollebesetning, 4) arbeid med tekst, 5) produksjonsfase, 6) internaliseringsfase og 7) konsolideringsfase. De dramaturgiske inngangene tid, tekst, kropp og rom rammer inn forløpet og definerer det didaktiske handlingsrommet. Vi identifiserer noen sentrale trekk ved fasene, der noen faser får mer utfyllende omtale enn andre. Ved hver fase tar vi først utgangspunkt i regissørens arbeid (omtalt som «hun») før vi speiler regissørens arbeid i teatret mot lærerens arbeid i klasserommet («han»).

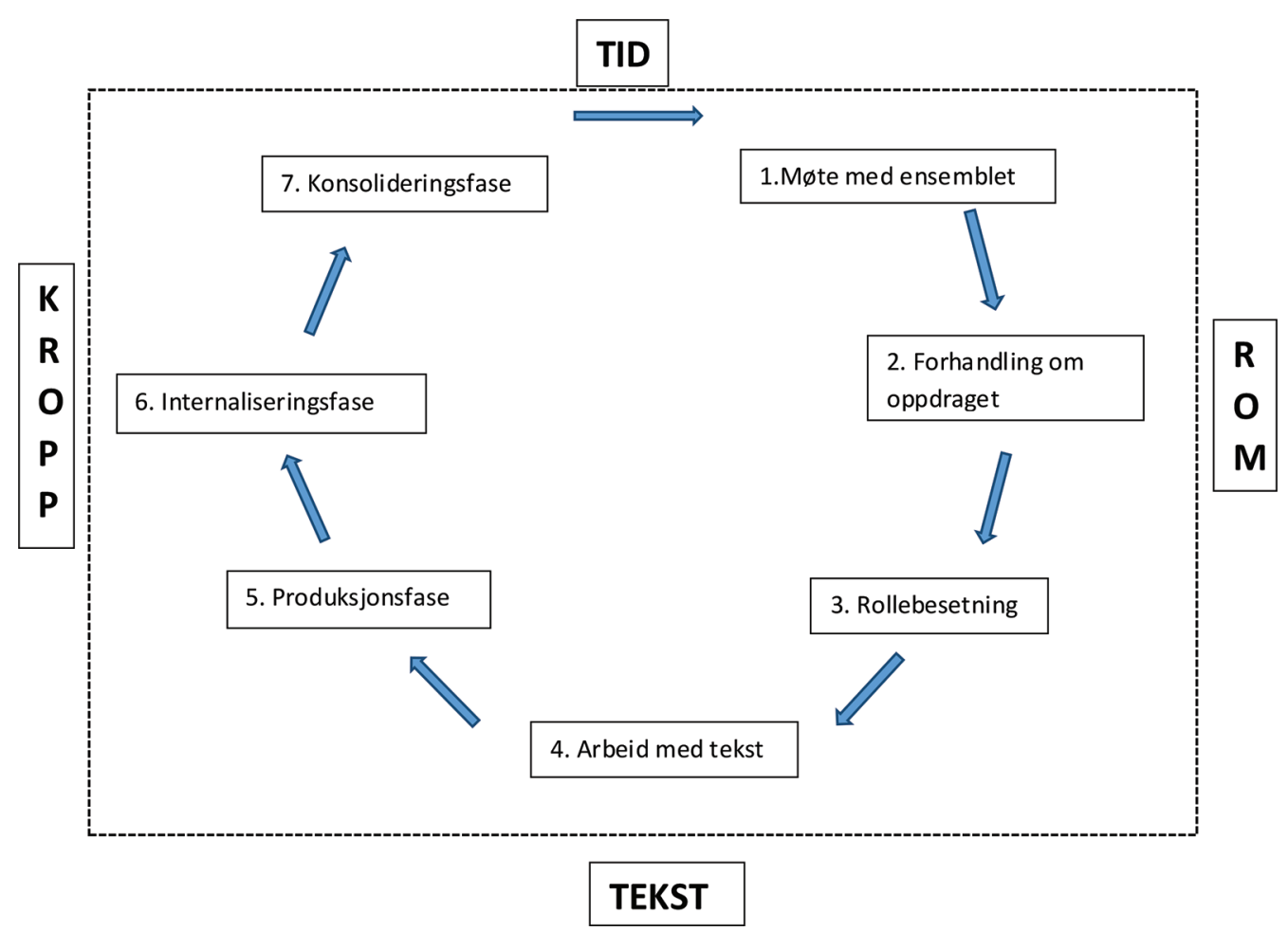

Figur 1. Dramaturgisk didaktikk, læringssirkel i sju faser 


\section{K.Helstad og P. A. Øiestad}

\section{Fase 1: Møte med ensemblet}

Når en teaterregissør møter sitt ensemble, er hensikten å bli raskt kjent for å komme i gang med arbeidet. Regissøren skaper tro på produksjonen ved å motivere skuespillerne og ved å ha tydelige visjoner for arbeidet. Hun vurderer potensialet hos hver enkelt og hos ensemblet som helhet. Sammen skal de eksperimentere og utforske hva som ligger i materialet de har til rådighet. Løsningene ligger ikke bare hos regissøren, men like mye i det som oppstår mellom skuespillerne og regissøren i prosessen.

Når læreren møter en klasse for første gang er han opptatt av å bygge relasjoner til elevene. Hvem er deltakerne i dette fellesskapet, og hva bringer de med seg? Han kartlegger dynamikken elevene imellom og observerer det sosiale samspillet. Læreren innvier elevene i sine visjoner og planer for arbeidet. Han uttrykker positive forventninger og motiverer elevene til innsats. Ved å legge premisser for hvordan arbeidet skal foregå, legitimerer læreren seg som leder i klasserommet. Slik bygger læreren relasjoner til elevene både som individer og som gruppe. Elevene får tillit til at læreren vil lede dem gjennom læringsprosessene.

\section{Fase 2: Forhandlinger om oppdraget}

I teatret er det i møte mellom en regissør og et ensemble at forhandlingene om oppdraget begynner. Hva slags idéer eller tekster skal iscenesettes, og hvordan skal de nærme seg dette stoffet? I denne fasen tilrettelegger regissøren for utforskende samtaler om forståelse av materialet som ligger til grunn for forestillingen.

Lærerens forhandlinger med elevene dreier seg på tilsvarende vis om forståelse av arbeidet de skal i gang med. Hva er formålet med dette undervisningsforløpet, og hvordan forstår elevene og læreren oppdraget? Selv om rammene er fastsatt i læreplaner, må læreren og elevene forhandle om hvordan kompetansemålene for faget kan tolkes, og hvordan de kan iscenesettes i klasserommet. Elevene involveres i hvordan læringsarbeidet kan tilrettelegges, og hvordan det faglige innholdet kan utformes gjennom varierte arbeidsmåter og vurderingsformer. Demokratiske prosesser innebærer at elevene skal høres og delta aktivt, men læreren er lederen som tar de endelige beslutningene.

\section{Fase 3: Rollebesetning}

Når regissøren har gjort seg kjent med ensemblet og skuespillerne har et forhold til stoffet som skal iscenesettes, skal rollene, hvis de ikke er besatt på forhånd, besettes. Skuespillerne skal ikke bare fylle rollene, de skal også bidra til å skape god energi i samspillet. Er hovedrolleinnehaveren sterk på scenen, er det viktig å sette sterke skuespillere i biroller. Hvis ikke kan det oppstå et asymmetrisk spill, der hovedrollene kan ta for mye plass. Alle i ensemblet har et ansvar for å levere sitt ypperste for at produksjonen og forestillingen skal bli så bra som mulig.

I klasserommet har læreren ansvar for å bevisstgjøre elevene på hvordan de inntar og utvikler sine sosiale roller og hvordan dynamikken elevene i mellom påvirker 
læringsmiljøet. Hvordan bygge en fellesskapskultur i klassen? Læreren kan eksperimentere med klasserommets scenografi, hvem han plasserer hvor og regissere aktiviteter der elevene får brynt seg på hverandre. Å la elevene samarbeide i ulike grupper og situasjoner er viktig for at det faglige arbeidet skal bli produktivt.

\section{Fase 4: Arbeid med tekst}

I teatret er regissørens og skuespillernes arbeid godt i gang. Tekster av ulike formater og sjangre, både klassiskere og samtidstekster, kan ligge til grunn. Regissøren leser tekstene med ensemblets og publikums blikk. Hun leser kritisk og analyserer tekstpassasjer og scener som driver handlingen framover. Tekstene bearbeides i samarbeid med skuespillerne. Rekkefølgen endres, scener omredigeres, tekst strykes, noe legges til. Tekstene bearbeides dramaturgisk for å fortelle historiene på nye måter.

Læreren regisserer tekstarbeidet i klasserommet. Mål og innhold i faget skal tilpasses konteksten og klasserommets her og nå. Som regissøren må læreren, sammen med elevene, gjøre tekstene i faget relevante og være kritisk til kildene. Kunnskap forskes ved at lærere og elever stiller spørsmål til læreverk og læringsressurser. Kronologien stokkes om, nye ideer inkorporeres, tverrfaglige temaer tas inn. Læreren leder an i disse prosessene og er eksperten i klasserommet. Han underviser og veileder elevene, han har et repertoar av arbeidsmåter og evne til å improvisere når uforutsette situasjoner oppstår. Han behersker didaktiske verktøy som gjør at han kan differensiere og skreddersy undervisningen både til klassen som helhet og til enkeltelevene.

\section{Fase 5: Produksjonsfase}

I produksjonsfasen begynner arbeidet med å utforske manus og materialets muligheter. Når regissør og skuespillere leser et manus og utforsker tekstens muligheter, får teksten liv. Å arbeide prosessorientert med tekster kan forstås som en tredelt prosess; teksten transformeres fra å være endimensjonal, som bokstaver på papir eller skjerm, til å bli todimensjonal, når skuespillerne tar teksten ut på gulvet, for til slutt å bli tredimensjonal når teksten levendegjøres og blir kollektivt eie i rommet. Skuespillernes fysiske plassering og måter de formidler tekst på åpner for lag av undertekst og gjør arbeidet rikt og komplekst. Teksten vokser ut av sitt eget format, som en frittstående skulptur folder teksten seg ut og kan observeres og utforskes fra ulike synsvinkler. I arbeidet med å levendegiøre teksten kommer tekstens iboende arkitektur til syne. Teksten utvikler seg fra å være et spinkelt reisverk til å skape sitt eget univers der handlingene utspiller seg. Regissør og ensemble bygger og perfeksjonerer tekstarbeidet ved å ta i bruk ulike sceniske virkemidler samtidig som rollekarakterene utformes. Produksjonsfasen blir en kollektiv prosess der regissør og skuespillere sammen lytter seg fram til og lander nødvendige kunstneriske valg.

Elevenes møte med tekster i skolen gjennomgår tilsvarende prosesser. Fagstoffet beveger seg fra å være endimensjonale tekster, papirbaserte eller digitale, til å løftes ut i læringsrommet og bli internalisert i elevenes forståelser. Læring skjer både på 


\section{K.Helstad og P. A. Øiestad}

individnivå, på gruppenivå og i klassefellesskapet. Når tekstene møter elevenes blikk og bryner seg på elevenes erfaringshorisont begynner tekstene å leve. Elevenes forståelse av lærestoffet bidrar til at kunnskap får språk som omsettes i kollektivt samspill. Læreren regisserer dette læringsarbeidet og felles forståelser av tekster som har vært i omløp blir forhandlet fram i klassesamtaler. Læringsprosessene integreres i dramaturgien som vokser fram i det flerstemmige klasserommet.

\section{Fase 6: Internaliseringsfase}

Det nærmer seg siste del av produksjonsfasen i teatret. De fleste arrangementer er satt, teksten er nesten definert, og skuespillerne er manusfrie. Regissør og ensemble jobber med tempo, flyt og skift mellom scenene. Noen justeringer må til, «darlinger» skal drepes, og regissøren må fram med saks, fordi forestillingen skal klippes og spisses. Teknikken må opp å stå, lys og lyd skal på plass, og «kost og mask» må fungere. Regissøren tar de siste avgjørende kunstneriske valgene før premieren.

I klasserommet går undervisningsforløpet mot sin avslutning. Det nærmer seg slutten på undervisningsforløpet. Ennå gjenstår det tid før arbeidet skal konsolideres. I denne fasen er det tid for finpuss og en siste innsats. Læreren repeterer sentralt stoff sammen med elevene. Hvis det nærmer seg eksamen, brukes tidligere eksamensoppgaver som modelltekster. Elevene rustes for skriftlige og muntlige vurderingssituasjoner. Klassen har oppøvd kunnskap og ferdigheter som danner grunnlaget å stå på når det gjelder. Men læreren vet at det var alt som gikk forut for denne fasen som virkelig gjaldt.

\section{Fase 7: Konsolideringsfase}

Premieren står for døren. Regissøren tenker på prosessen fra det første møtet med ensemblet og fram til nå, der hun snart skal gjøre sin sorti. Hun tenker på arbeidsfellesskapet som har oppstått. De har eksperimentert og utforsket, vridd og knadd på tekster, de har jobbet fram forestillingen sammen. Om forestillingen føles uferdig, og regissøren tenker at arbeidet ikke er fullført, er øyeblikket likevel kommet. Regissøren samler ensemblet og takker for samarbeidet. Forestillingen skal leve sitt eget liv.

Undervisningsforløpet er over. Læreren har nok dokumentasjon til å vurdere elevenes arbeid. Læreren involverer elevene i refleksjonen over prosessene de har vært gjennom sammen. Han vet at drivkraften for læring ikke kan måles i karakterer. Kunnskap oppstår og produseres i fellesskap. Samtidig vet han at læringsarbeidet som har foregått vil ha betydning for elevenes liv og muligheter. Læreren tenker på dynamikken i klasserommet og på fasene de har vært i gjennom. Han husker elevenes fortolkninger av fagstoffet og tenker på alle forhandlingene i klasserommet, på tekstene som har vært i omløp. Han tenker på hvordan elevene har beveget seg inn og ut av tekstene $\mathrm{i}$ faget han har undervist i. Han tenker på de utforskende og kreative prosessene de har opplevd sammen og kjenner på takknemlighet over det han har vært med på. Samtidig er han undersøkende til egen praksis: Ga han elevene nok utfordringer, fanget han godt nok opp de som strevde? Læreren tenker at hvis det var mulig, ville han tatt med 
seg elevene opp på glasstaket. Derfra kunne de sammen observere linjene mellom fag og kunnskapsområder i og på tvers av klasserommet. Nye sammenhenger ville kunne anes, og konturene av en helhet ville tre tydeligere fram. Han får et bilde på netthinnen, der elevene beveger seg nesten som $i$ en dans. Han er koreografen som setter kunnskap i bevegelse. Han er regissøren, og nå er premieren kommet.

\section{Den dramaturgiske læringssirkelens potensiale i didaktisk arbeid}

I den dramaturgiske læringssirkelen har vi speilet lærerens arbeid i klasserommet mot regissørens arbeid i teatret for å utforske nye perspektiver på didaktiske kontekster. Teoretiske modeller er alltid forenklinger av virkeligheten, og den dramaturgiske læringssirkelen og tenkningen som ligger til grunn tar ikke mål av seg til å tilby noen uttømmende beskrivelse av undervisningsforløp. Hvis teorier og modeller følges slavisk, og lærere anvender dem instrumentelt, vil de fungere hemmende for lærernes evne til å improvisere og ta kontekstuelle valg når situasjonen krever det (Gladsø et al., 2015; Moltubak, 2020). Modeller kan imidlertid fungere som støttende stillas både i en planleggingsfase og en gjennomføringsfase, og som rammer for didaktisk arbeid. Et eksempel på slike stillas er den didaktiske relasjonsmodellen, som for mange lærere og studenter har fungert som et viktig redskap for å strukturere og kvalitetssikre undervisningen. På tilsvarende måte har Østern (2016, s. 269) utviklet en dramaturgisk analysemodell der teatrets forståelser er brukt i undervisningssammenheng, og Lindstøl (2017) har utviklet en modelleringsstige der lærerutdannere kan bestemme hvilke trinn som kan være hensiktsmessige i undervisningen. Didaktisk arbeid er sjelden karakterisert av lineære prosesser som kan planlegges kronologisk. Dette innebærer at læringssirkelen i praksis følger sin egen dramaturgi der forløp kan planlegges, men der dynamikken som utspiller seg mellom lærere, elever, fag og tekster i situasjonen de oppstår i kan ta uante veier. Den dramaturgiske læringssirkelen må dermed forstås som en idealtypisk måte å framstille transformasjonsprosesser. I virkeligheten vil lærere kunne bevege seg mellom fasene, og det vil kunne oppstå mini-sykluser av utprøving og refleksjon innenfor hver av fasene. Fasene kan være flere eller færre, de kan flyte over i hverandre og de kan stokkes om på. Lærere trenger verktøy for å håndtere det simultane og komplekse klasserommet. Den dramaturgiske læringssirkelen kan fungere som et av flere analyseverktøy og støttestrukturer for både studenter og lærere i dette arbeidet.

\section{Dramaturgisk didaktikk som virksomme handlinger}

Som omtalt innledningsvis, bygger den dramaturgisk-didaktiske tenkningen på et sammensatt teoritilfang av kunstfaglige forståelser, didaktisk relasjonstenkning (Bjørndal \& Liberg, 1978), pedagogisk teori (Dale, 1991) og ekspansiv læringsteori, som beskriver utviklingsarbeid i arbeidslivskontekster (Engestrøm \& Sannino, 2010). I ekspansiv læring stilles spørsmål ved eksisterende praksis som blir analysert for å 
avdekke eventuelle spenninger. Med utgangspunkt i historiske og empiriske analyser utformes en plan der nye ideer blir undersøkt før de kan implementeres og konsolideres i virksomheten. Dersom nye ideer ikke fungerer, blir de forkastet og aktivitetene kan beveges mot nye endringer. Overført til undervisning innebærer denne forståelsen at didaktisk arbeid kan være i kontinuerlig utvikling forutsatt at profesjonen selv (lærerne) stiller utforskende spørsmål til egen praksis og at de er forberedt på å håndtere spenninger som vil dukke opp (Eri \& Aas, 2020). Dramaturgisk didaktikk henter inspirasjon fra denne tenkningen ved å ha fokus på det som skjer i undervisningens her og nå i kombinasjon med et blikk for lengre forløp. Den dramaturgiske læringssirkelen illustrerer dette poenget ved å ramme inn en begynnelse og en slutt $i$ et undervisningsforløp, der fase 1 tar for seg møtet mellom lærere og elever, og der fase 7 avslutter og konsoliderer forløpet. I mellomrommet mellom lærerens entre og sorti oppstår et didaktisk handlingsrom, der elever og lærere sammen forhandler om forståelser av oppdraget. Her iscenesettes tekster, og kunnskap kan internaliseres. For læreren innebærer dette å være $i$ situasjonen, å kunne håndtere dynamikk og spenninger som vokser fram i relasjonelt og faglig klasseromsarbeid, samtidig som læreren tenker om situasjonen ved å anlegge et analytisk blikk for å sette arbeidet her og nå inn i en større sammenheng. Et dramaturgisk perspektiv på klasserommets didaktikk dreier seg om å kople læringsteorier med kunstfaglige perspektiver for å forstå hvordan lærere kan iscenesette undervisning som læringsprosesser med blikk for elevenes deltakelse og læring. Vi har visualisert teorien i form av en dramaturgisk læringssirkel der begrepene entré (etableringsfasen) og sorti (konsolideringsfasen) rammer inn en begynnelse og en slutt i et undervisningsforløp. Dramaturgisk didaktikk forstås med dette som virksomme handlinger som blir satt i spill i dette mellomrommet, der læreren tilrettelegger for læringsprosesser hvor elevene over tid får bryne seg på fag og relasjoner gjennom et pågående kunnskapsarbeid.

\section{Sammenfatning}

I forskning på profesjonsarbeid er det gjerne den språklig uttrykte og analytiske kunnskapen som har status. Det profesjonelle yrkesutøvere, som lærere, besitter av intuitiv og lite artikulert kunnskap er ofte underkommunisert i faglitteraturen (Nonaka \& Takeuchi, 1995). Lærerarbeidet har historisk sett foregått bak lukkede klasseromsdører og vært lite synlig i faglitteratur og forskning. Lærernes egne stemmer har vært få, noe som har sammenheng med at måten å utøve yrket på sitter i kroppen som teorikonstruksjoner om hva som «virker» (Kvernbekk, 2005). Det er behov for mer innsikt i hvordan lærere faktisk underviser, hvilke ressurser de trekker på i arbeidet og hvordan de iscenesetter læringsprosesser i samspill med elevene. Når forskningsbasert og erfaringsbasert kunnskap kombineres, kan det gi støtet til ny kunnskapsutvikling som kan komme både praksisfelt og forskning til gode. Forskningen og praksiserfaringene som ligger til grunn for denne artikkelen, der en lærer og en forsker har utviklet teorier om dramaturgisk didaktikk, er vårt bidrag til feltet. I 
artikkelen har vi utforsket hva dramaturgisk didaktikk kan innebære, og vi har undersøkt hvordan dramaturgiske verktøy kan stimulere både teorier om undervisning og arbeidet i klasserommet. Ved å undersøke om lærerarbeidet i klasserommet kan bli inspirert av regissørens arbeid i teatret har vi sett på mulige sammenhenger mellom dramaturgi, didaktikk og læringsteorier og utforsket hva fagfeltene kan tilføre hverandre. Verdien i et dramaturgisk perspektiv er at det fokuserer på dynamikken og mulighetene som ligger som potensiale i praksis og som kan bidra med nye forståelser av undervisning (Østern, 2016, s. 267). Både i skolen og i høyere utdanning er det nødvendig at undervisning og læringsarbeid utvikles og at det gis rom for nytekning. Vårt innspill til en dramaturgisk didaktikk dreier seg kort fortalt om lærerens tilrettelegging av virksomme handlinger fra begynnelse til slutt $\mathrm{i}$ et undervisningsforløp. Mens tradisjonell klasseromsdidaktikk gjerne tar for seg planleggingsdimensjonen ved undervisning, tilbyr en dramaturgisk tilnærming beskrivelser av forløp som kan bidra til mer nyanserte forståelser. Mulige implikasjoner dreier seg om at lærere og studenter i lærerutdanning bør tilbys alternative forståelser og et rikere språk for didaktisk arbeid. Spesielt bør de kunne nyttiggiøre seg av mulighetene som ligger i å tenke dramaturgisk. For klasseromforskning kan studier der undervisning granskes med et dramaturgisk blikk tilby ny kunnskap. Undervisning og læring er sammensatte og komplekse aktiviteter. Dramaturgisk tenkning kan bidra til at lærere bedre kan identifisere faser $i$ et undervisningsforløp og forholde seg mer bevisst til dynamikken som iscenesettes i klasserommet. Å tenke som en dramaturg kan bidra til å profesjonalisere arbeidet og giøre lærere bedre rustet til å møte klasserommets mange utfordringer.

\section{Forfatterbiografi}

Kristin Helstad er professor i pedagogikk ved Høgskolen i Innlandet. Hun har 15 års erfaring som lærer- og skolelederutdanner fra Universitetet i Oslo og tidligere erfaring som lærer, skoleleder og forlagsredaktør. Helstad har utgitt en rekke artikler og bøker på norsk og engelsk, blant annet Nye lerer- og lederroller $i$ skolen (Helstad \& Mausethagen, 2019) og Profesjonsutvikling i skolen (Elstad \& Helstad, 2014).

Per Arne Øiestad er lektor i drama og teaterfag ved Hartvig Nissens skole i Oslo. Han også utdannet dramatiker og har lang erfaring som regissør og lærebokforfatter. Øiestad og Helstad er forfattere av boken Leereren som regissør. Verktøy for ledelse $i$ klasserommet (2017) som de vant Cappelen Damms forfatterstipend for.

\section{Referanser}

Allern, T. H. \& Sæbø, A. B. (2010). Hva kan drama som læringsform bidra med i undervisnings- og læringsprosessen? Norsk pedagogisk tidsskrift, 94(3), 244-255. https://doi.org/10.18261/ISSN1504-29872010-03-06

Alvesson, M. \& Sköldberg, K. (2010). Tolkning och reflektion: vetenskapsfilosofi och kvalitativ metode. Studentlitteratur AB. 


\section{K.Helstad og P. A. Øiestad}

Bakke, J. O. (2019). Skriveforløpets dramaturgi: A iscenesette et skriveoppdrag. En kvalitativ studie av skriveundervisning $i$ norsk, samfunnsfag og naturfag på 7. trinn, gjennomført $i$ Normprosjektet [Doktorgradsavhandling, Universitetet i Sørøst-Norge]. USN Open Archive. http://hdl.handle.net/11250/2582386

Bakke, J. O. \& Lindstøl, F. (2021). Chasing fleeing animals - on the dramaturgical method and the dramaturgical analysis of teaching. Research in Drama in Education: The fournal of Applied Theatre and Performance, 26(2), 283-299. https://doi.org/10.1080/13569783.2021.1885370

Bjørndal, K. \& Lieberg, S. (1978). Nye veier i didaktikken? En innføring $i$ didaktiske emner og begreper. Aschehoug.

Blikstad-Balas, M. \& Roe, A. (2020). Hva skjer i norsktimene? Universitetsforlaget.

Cochran-Smith, M. \& Lytle, S. L. (2015). Inquiry as Stance: Practitioner Research for the Next Generation. Teacher College Press.

Christoffersen, C. (2011). Interesser, nærhet og brudd. Om å forske på egen musikkpedagogisk kultur. Nordisk musikkpedagogisk forskning, Arbok 12, 31-42.

Dale, E. L. (1991). Kunnskapens tre og kunstens skjønnhet. Om den estetiske oppdragelse $i$ det moderne samfunn. Gyldendal.

Engestrøm, Y. \& Sannino, A. L. (2010). Studies of expansive learning: Foundations, findings and future challenges. Educational research Review, 5(1), 1-24. https://doi.org/10.1016/j.edurev.2009.12.002

Eriksen, A. \& Leming, T. (2020). Drama og teater som tilnærming i aksjonsforskning - å øve på framtida. I S. Gjøtterud, H. Hiim, D. Husebø \& L. H. Jensen (Red.), Aksjonsforskning $i$ Norge, volum 2: Grunnlagstenkning, forskerroller og bidrag til endring $i$ ulike kontekster (s. 281-301). Cappelen Damm Akademisk. https://doi.org/10.23865/noasp.121

Fredens, K. (2019). Lering - et samspill mellom hjerne, kropp og omverden. Cappelen Damm Akademisk.

Gladsø, S., K. Gjervan, E., Hovik, L. \& Skagen. A. (2015). Dramaturgi: Forestillinger om teater (2. utg). Universitetsforlaget.

Gundem, B. B. (2008). Didaktikk - fagdidaktikk, anstrengte eller fruktbare forhold? Acta Didactica Norge, 2(1), 1-15. https://doi.org/10.5617/adno.1020

Helstad, K. \& Øiestad, P. A. (2017). Lereren som regissør. Verktøy for ledelse $i$ klasserommet. Cappelen Damm Akademisk.

Hermansen, H. (2018). Kunnskapsarbeid i lererprofesjonen. Universitetsforlaget.

Hiim, H. (2020). Likheter og forskjeller mellom tilnærminger til aksjonsforskning. En analyse av prinsipper og dilemmaer relatert til forskningens hensikt, utviklingsmetoder, forskerrollen og epistemologisk grunnlag i noen sentrale tilnærminger. I S. Gjøtterud, H. Hiim, D. Husebø \& L. H. Jensen (Red.), Aksjonsforskning $i$ Norge, volum 2: Grunnlagstenkning, forskerroller og bidrag til endring $i$ ulike kontekster (s. 25-54). Cappelen Damm Akademisk. https://doi.org/10.23865/noasp.121

Klette, K. (2020). Hva vet vi om god undervisning? I R. J. Krumsvik \& R. Saljø (Red.), Praktisk-pedagogisk utdanning. En antologi. (2. utg.). (s. 183-206) Fagbokforlaget.

Kvale, S. \& Brinchmann, S. (2015). Det kvalitative forskningsintervju. Gyldendal Akademisk.

Kvernbekk, T. (2005). Pedagogisk teoridannelse: Insidere, teoriformer og praksis. Fagbokforlaget.

Lindstøl, F. (2017). Mellom risiko og kontroll - en studie av eksplisitte modelleringsformer i norsk grunnskolelærerutdanning. Fournal for Research in Arts and Sports Education, 3(1), 1-19. https://doi.org/10.23865/ntpk. v3.734

Moltubak. J. (2020). Improvisasjon i klasserommet. Universitetsforlaget.

Møller, J. (2019). Nye leder- og lærerroller i skolen - konsekvenser for rektorrollen. I K. Helstad \& S. Mausethagen (Red.), Nye lcerer-og lederroller $i$ skolen. (s. 185-201) Universitetsforlaget.

Nonaka, I. \& Takeuchi, H. (1995). The knowledge-creating company. Oxford University Press.

Postholm, M. B. \& Smith, K. (2017). Praksisrettet forskning og formative intervensjonsforskning; forskning for utvikling av praksisfeltet og vitenskapelig kunnskap. I S. Gjøtterud, H. Hiim, D. Husebø, L. Jensen, T. Steen-Olsen \& E. Stjernestrøm (Red.), Aksjonsforskning $i$ Norge. Teoretisk og empirisk mangfold (s. 71-94). Cappelen Damm Akademisk. https://doi.org/10.23865/noasp.17

Rasmussen, J., Kruse, S. \& Holm, C. (2007). Viden om uddannelse. Uddannelsesforskning, pedagogik og pedagogisk praksis. Hans Reitzels Forlag.

Szatkowski, J. (1989). Dramaturgiske modeller - om dramaturgisk tekstanalyse. I E. E. Christoffersen, T. Kjølner \& J. Szatkowski (Red.), Dramaturgisk analyse. En antologi (s. 9-92). Universitetet i Århus, Institutt for dramaturgi.

Utdanningsdirektoratet. (2021). Lereplan i teater i perspektiv (DRA03-02). https://www.udir.no/lk20/DRA03-02

Østern, A.-L. (2014). Å tenke som en dramaturg i undervisningen. I A.-L. Østern (Red.), Dramaturgi i didaktisk kontekst (s. 19-37). Fagbokforlaget.

Østern, A. L. (2016). Dramaturgens blikk på veiledningens praktiske didaktikk. I A.-L. Østern \& G. Engvik (Red.), Veiledningspraksiser $i$ bevegelse. (s. 265-284). Fagbokforlaget. 